\title{
Extraction and Characteristic of Gelatin from Milkfish (Chanos chanos) Scales and Bones with Variation in Acid and Base Concentrations, Extracting and Drying Method
}

\author{
Isriany Ismail $^{1}$, Nursalam Hamzah ${ }^{2}$, Siti Qurrataayyun ${ }^{3}$, Sri Rahayu ${ }^{4}$, Karlina Amir Tahir $^{5}$, M. Natsir Djide ${ }^{6}$ \\ \{isriany.ismail@uin-alauddin.ac.id ${ }^{1}$, nursalam.hamzah@uin-alauddin.ac.id ${ }^{2}$, sitiqurrataayyun96@gmail.com ${ }^{3}$, \\ rahayusri575@gmail.com ${ }^{4}$, karlina.amir@uin-alauddin.ac.id ${ }^{5}$,natsirdj@yahoo.com $\left.{ }^{6}\right\}$ \\ 1,2,3,4,5 Departement of Pharmacy, Faculty of Medicine and Health Science, Universitas Islam Negeri Alauddin Makassar, \\ Indonesia. 92113 \\ ${ }^{6}$ Departement of Pharmacology, Faculty of Pharmacy, Universitas Hasanuddin, Indonesia. 90245
}

\begin{abstract}
This study aims to determine the optimum conditions for extracting gelatin from milkfish (Chanos chanos) scales and bones. Scales and bond milkfish were pre-treated with $0.01 \mathrm{~N}, 0.1 \mathrm{~N}$ and $1 \mathrm{~N}$ of sodium hydroxide and acetic acid; extraction used water bath $\left(60{ }^{\circ} \mathrm{C}, 8\right.$ hours $)$, sonicator $\left(50{ }^{\circ} \mathrm{C}, 3\right.$ hours $)$, microwave $\left(100{ }^{\circ} \mathrm{C}, 1\right.$ hour$)$, and autoclave $\left(121^{\circ} \mathrm{C}, 1\right.$ hour $)$; and drying used dry hot air $\left(60^{\circ} \mathrm{C}\right)$ and freeze dried $\left(-40^{\circ} \mathrm{C}\right)$. The characteristics of gelatin determined with measuring viscosity, $\mathrm{pH}$ and yield. The most optimal method ( $\mathrm{p}$ $<0.05$ ) for extraction of milkfish scales and bones used $1 \mathrm{~N}$ acetic acid for 8 hours (pretreatment process), water bath $60^{\circ} \mathrm{C}, 8$ hours for hydrolysis methods and freeze dried for the drying methods. The characteristics of gelatin viscosity, $\mathrm{pH}$ and yield were $3.3890 \mathrm{cP}, 4.6$, and $1.9 \%$ respectively, while milkfish scales were $4.6759 \mathrm{cP}, 5.4$ and $3.7 \%$. Gelatin produced from bone can be used for food and pharmaceutical ingredients (hard, soft capsule, and tablets) while those from scales can be used for food and pharmaceutical ingredients (hard capsule).
\end{abstract}

Keywords: Milkfish, Gelatin, Viscosity, Bone, Scales.

\section{Introduction}

Gelatin needs increase from year to year for the food and pharmaceutical industry, because gelatin is one of the ingredients that is often use as an additional ingredient to increase the elasticity, consistency, and reliability of the preparation (Elgadir et.al, 2013; Gimenez Et.Al, 2005).

Most commercial gelatin, which is 326,000 tons of world gelatin production annually, comes from cattle bone (29.4\%), bone, skin and soft tissue (41-46\%) (Elgadir et.al, 2013; GMIA, 2012). Some problems that have come to the fore and become a concern of producers in recent years, namely the need for halal products in countries with a majority Muslim population, including countries with high Muslim consumer visits also for healthier sources of gelatin (Tavakolipour, 2011; Elgadir et.al, 2013). Therefore it is necessary to develop sources of gelatin other than those originating from other mammals or non-mammals that have quality according to the standards of use in the food and pharmaceutical industries according to the requirements (GMIA, 2012).

Fish gelatin represents one of the types of non-mammalian gelatin that has the potential to be developed considering the fish byproducts in the form of skin, scales, fins, and bones containing collagen (Silvipriya et al., 2015; Zakaria, Hidayah, \& Bakar, 2015). Hydrolysis of collagen will produce gelatin. The quality of gelatin is influenced by the extraction process, including the selection of types and concentrations of acid (Dinçer, Ağçay, Sargin, \& Bayram, 2015) or base (Badii \& Howell, 2006), temperature (Choi \& Regenstein, 2000), soaking time, and drying method as reported by many researchers. Sompie reported that the difference in extraction temperature had a different effect $(\mathrm{P}>0.05)$ on yield, gel strength, and viscosity of gelatin chicken leg skin $($ Sompie et.al, 2015). The use of variations in $\mathrm{NaOH}$ concentration, acetic acid, and temperature variations with a fixed immersion time (3 hours) produced gelatin products of different qualities. The condition of the best gelatin extraction process from kumakuma fish skin was obtained at immersion for 6 hours and a temperature of $58^{\circ} \mathrm{C}$ and produced gelatin considered as food ingredients (Silva et,al, 2017).

The quality of gelatin is important to note. This is related to the quality of the product that produced. Gelatins produced according to food standards, pharmaceuticals, photography, and industry are needed to meet the consumption of colloidal materials in the food, pharmaceutical and other industries (Benjakul, Kittiphattanabawon, \& Regenstein, 2012). Pharmaceutics standard gelatin must meet the quality according to monograph, namely isoelectric point, gel strength, viscosity, ability to form a thermo reversible gel, water binding capacity, pH stability and ash content (GMIA, 2012).

Many researchers have reported the potential use of fish gelatin for the food industry, including gelatin from the skin of giant catfish and tilapia (Rawdkuen, Thitipramote, \& Benjakul, 2013); gelatin from kumakuma fish skin can replace agar from 
mammals with gel strength $244.3 \mathrm{~g}$ (Silva et al., 2017); the skin of Catla (Catla catla), black tilapia (Oreochromis mossambicus), naked catfish (Pangasius hypophthalamus) and Black kingfish (Ranchycentron canadus) show high gel strength and properties similar to gelatin cow skin (Koli, Sagar, Kamble, \& Sharangdhar, 2014).

Fish gelatin as an alternative food and pharmaceutical raw material must be available in large quantities and at affordable prices so that it can be widely used. Therefore it is necessary to find the optimum extraction conditions from non-mammalian gelatin sources, especially from fish byproducts.

\section{$2 \quad$ Material and Methods}

Bone and scales of milkfish (Chanos chanos) are taken from the fish processing industry of PT Usaha Centraljaya Sakti, Makassar Industrial Area, South Sulawesi, Indonesia. Arriving in the laboratory, immediately cleaned with tap water three times, dried and stored at $-5{ }^{\circ} \mathrm{C}$ until used. Acetic acid $\left(\mathrm{CH}_{3} \mathrm{COOH}\right)$, distilled water $\left(\mathrm{H}_{2} \mathrm{O}\right)$, hydrochloric acid $(\mathrm{HCl})$, sodium hydroxide $(\mathrm{NaOH})$ using Merck ${ }^{\circledR}$ production.

\section{Gelatin Extraction}

Gelatin extraction followed the procedure according to Nazmi, Isa and Sarbon (Nazmi, Isa, \& Sarbon, 2017) by modification.

\section{Pre-treatment}

250 grams of bone and milkfish scales were prepared for each of the 11 groups. Each group is separately mixed with $\mathrm{CH}_{3} \mathrm{COOH}$ or $\mathrm{NaOH}$ with concentration and soaking time as in Table 1 . The immersion results are then filtered and neutralized by adding $\mathrm{NaOH} / \mathrm{HCl} /$ washed with distilled water then filtered. The ossein residue is prepared for the next procedure.

\section{Extraction}

Ossein is soaked with distilled water at $50-100^{\circ} \mathrm{C}$ using a different equipment, water bath (Mammert ${ }^{\circledR}$ ), sonicator VWR $\AA$, microwave Modena ${ }^{\circledR}$ and autoclave Hirayama HVE-50 ${ }^{\circledR}$ with different soaking and temperature times as in Table 1 . The mixture is then filtered and the filtrate is collected for dried.

\section{Drying}

The filtrate is dried by a different method, dry hot air using oven Mammert ${ }^{\circledR}$ and freeze dried (Nazmi et al., 2017) using freeze drier Chaist Alpha 1-2 LD Plus ${ }^{\circledR}$ (Table 1)

\section{Characterization of Gelatin}

\section{Organoleptic}

Observation of color, smell, texture, and shape of gelatin

\section{Gelatin Yield}

Yield gelatin was determined by the formula (Nurul, A.G. \& Sarbon, 2015)

$$
\% \text { gelatin yield }=\frac{\text { Gelatin weight }}{\text { dry bone or scale weight }} \times 100 \%
$$

\section{Viscosity}

The $0.67 \%$ gelatin concentration was completely dissolved in distilled water $\left(70^{\circ} \mathrm{C}\right)$, and the viscosity was measured using the Ostwald viscometer at a temperature of $20^{\circ} \mathrm{C}$ using the formula

$$
\frac{\eta \text { water }}{\eta \text { sample }}=\frac{\rho \text { water } \mathrm{x} \text { t water }}{\rho \text { sample } \mathrm{x} \mathrm{t \text {sample }}}
$$

\section{pH}

Gelatin $1 \%(\mathrm{w} / \mathrm{v})$ was completely dissolved in distilled water $\left(70^{\circ} \mathrm{C}\right) \mathrm{pH}$ was measured at $25^{\circ} \mathrm{C}$ using a pH meter Venske ${ }^{\circledR}$ which has been calibrated beforehand.

\section{Analysis Methods}

Viscosity and $\mathrm{pH}$ parameters used international gelatin standards (GMIA, 2012). Statistical analysis used the Analysis Variant (ANAVA) method. The comparison of the average used Duncan's multiple range tests to assess the difference in viscosity of each group using the IBM SPSS 22.00 application. 


\section{Results and Discussion}

This study attempted to find the optimum extraction conditions that could produced gelatin from milkfish bones and scales with viscosity and acidity that can be accepted to used in foods and pharmaceutical preparations according to the international standard characteristics of gelatin type $\mathrm{A} \mathrm{pH} \mathrm{3.8-5.5} \mathrm{and} \mathrm{type} \mathrm{B}$ pH 5-7,5; the viscosity of gelatin for type A 1.5-7.5 cP and type B 2.0-7.5 cP (GMIA, 2012: 12).

Optimization procedures designed start from the used of acids or bases with different concentrations (pre-treated), used of water bath, autoclave, sonication, and microwave for optimization of collagen hydrolysis methods, and used different drying methods using oven dan freeze-dried. The design procedure for optimizing gelatin extraction was presented in table 1 .

Table 1. Procedure Design for Optimizing the Extraction of Gelatin from Milkfish Bones \& Scales

\begin{tabular}{|c|c|c|c|c|c|c|c|c|c|c|c|c|c|}
\hline \multirow{3}{*}{$\begin{array}{l}\mathbf{N} \\
\mathbf{O}\end{array}$} & \multirow{3}{*}{\multicolumn{2}{|c|}{ TREATMENT }} & \multicolumn{11}{|c|}{ GROUP } \\
\hline & & & 1 & 2 & 3 & 4 & 5 & 6 & 7 & 8 & 9 & 10 & 11 \\
\hline & & & \multicolumn{8}{|c|}{ ACETIC ACID } & \multicolumn{3}{|c|}{$\begin{array}{c}\text { SODIUM } \\
\text { HYDROXIDE }\end{array}$} \\
\hline 1 & Conce & tration $(\mathrm{N})$ & 0,01 & 0,1 & \multicolumn{6}{|c|}{1} & 0.01 & 0,1 & 1 \\
\hline 2 & Soaki & g time $(\mathrm{h})$ & 8 & 8 & 8 & 8 & 12 & 12 & 12 & 8 & 8 & 8 & 8 \\
\hline 3 & Neu & $\begin{array}{l}\text { alization } \\
\text { ethod }\end{array}$ & $\begin{array}{c}\mathrm{NaO} \\
\mathrm{H}\end{array}$ & $\begin{array}{c}\mathrm{NaO} \\
\mathrm{H}\end{array}$ & $\mathrm{NaOH}$ & $\begin{array}{l}\text { Distille } \\
\text { d water }\end{array}$ & $\begin{array}{l}\text { Distille } \\
\text { d water }\end{array}$ & $\begin{array}{l}\text { Distill } \\
\text { ed } \\
\text { water }\end{array}$ & $\begin{array}{l}\text { Distille } \\
\text { d water }\end{array}$ & $\begin{array}{l}\text { Distille } \\
\text { d water }\end{array}$ & $\mathrm{HCl}$ & $\mathrm{HCl}$ & $\mathrm{HCl}$ \\
\hline \multirow[t]{4}{*}{4} & \multirow[t]{4}{*}{$\begin{array}{l}\text { Extractio } \\
\mathrm{n} \text { Method }\end{array}$} & $\begin{array}{l}\text { Water } \\
\text { bath }\end{array}$ & $\begin{array}{c}8 \mathrm{~h} \\
60^{\circ} \mathrm{C}\end{array}$ & $\begin{array}{c}8 \mathrm{~h} \\
60^{\circ} \mathrm{C}\end{array}$ & $\begin{array}{c}8 \mathrm{~h} \\
60^{\circ} \mathrm{C}\end{array}$ & $\begin{array}{c}8 \mathrm{~h} \\
60^{\circ} \mathrm{C}\end{array}$ & - & - & - & $\begin{array}{c}8 \mathrm{~h} \\
60^{\circ} \mathrm{C}\end{array}$ & $\begin{array}{l}8 \mathrm{~h} \\
60 \\
{ }^{\circ} \mathrm{C}\end{array}$ & $\begin{array}{l}8 \mathrm{~h} \\
60 \\
{ }^{\circ} \mathrm{C}\end{array}$ & $\begin{array}{l}8 \mathrm{~h} \\
60 \\
{ }^{\circ} \mathrm{C}\end{array}$ \\
\hline & & Sonicator & - & - & - & - & $\begin{array}{c}3 \mathrm{~h} \\
50^{\circ} \mathrm{C}\end{array}$ & - & - & - & - & - & - \\
\hline & & $\begin{array}{c}\text { Microwav } \\
e\end{array}$ & - & - & - & - & - & $\begin{array}{c}1 \mathrm{~h} \\
100^{\circ} \\
\mathrm{C}\end{array}$ & - & - & - & - & - \\
\hline & & Autoclave & - & - & - & - & - & - & $\begin{array}{c}1 \mathrm{~h} \\
121^{\circ} \mathrm{C}\end{array}$ & - & - & - & - \\
\hline 5 & \multicolumn{2}{|c|}{ Dry hot air (Oven) } & $\begin{array}{l}48 \mathrm{~h} \\
60^{\circ} \mathrm{C}\end{array}$ & $\begin{array}{l}48 \mathrm{~h} \\
60^{\circ} \mathrm{C}\end{array}$ & $\begin{array}{l}48 \mathrm{~h} \\
60^{\circ} \mathrm{C}\end{array}$ & $\begin{array}{l}48 \mathrm{~h} \\
60^{\circ} \mathrm{C}\end{array}$ & $\begin{array}{l}48 \mathrm{~h} \\
60^{\circ} \mathrm{C}\end{array}$ & $\begin{array}{c}48 \\
\mathrm{~h} \\
60^{\circ} \mathrm{C}\end{array}$ & $\begin{array}{l}96 \mathrm{~h} \\
60^{\circ} \mathrm{C}\end{array}$ & - & $\begin{array}{c}96 \mathrm{~h} \\
60^{\circ} \\
\mathrm{C}\end{array}$ & $\begin{array}{c}120 \\
\mathrm{~h} \\
60^{\circ} \\
\mathrm{C}\end{array}$ & $\begin{array}{c}96 \mathrm{~h} \\
60^{\circ} \\
\mathrm{C}\end{array}$ \\
\hline 6 & \multicolumn{2}{|c|}{ Freeze Dry } & - & - & - & - & - & - & - & $\begin{array}{c}96 \mathrm{~h} \\
-40^{\circ} \mathrm{C}\end{array}$ & - & - & - \\
\hline
\end{tabular}

Table 2. Results of observations of Gelatin Organoleptics from Milkfish Bones \& Scales

\begin{tabular}{|c|c|c|c|c|c|c|c|c|}
\hline \multirow[t]{2}{*}{ Group } & \multicolumn{2}{|c|}{ Color } & \multicolumn{2}{|c|}{ Smell } & \multicolumn{2}{|c|}{ Texture } & \multicolumn{2}{|c|}{ Form } \\
\hline & Bone & Scale & Bone & Scale & Bone & Scale & Bone & Scale \\
\hline 1 & Brownish white & Grey & & & Smooth & Smooth & Powder & Film \\
\hline 2 & Brownish yellow & Brownish yellow & & & Rude & Rude & Film & Film \\
\hline 3 & Yellowish white & white & & & Rude & Rude & Powder & Powder \\
\hline 4 & Brownish yellow & Yellowish white & & & Kasar & Smooth & Film & Film \\
\hline 5 & white & white & & & Smooth & Rude & Powder & Powder \\
\hline 6 & Yellowish white & white & & & Smooth & Smooth & Film & Film \\
\hline 7 & Brown & Brownish yellow & & & Rude & Rude & Chip & Chip \\
\hline 8 & Yellowish white & white & & & Smooth & Smooth & Film & Film \\
\hline 9 & Brownish yellow & Brown & & & Rude & Smooth & Powder & Film \\
\hline 10 & Brownish yellow & Yellowish white & & & Rude & Rude & Powder & Film \\
\hline 11 & Brownish yellow & Brownish yellow & & & Rude & Rude & Chip & Film \\
\hline
\end{tabular}

The pre-treatment process was the initial procedure before extracting gelatin for removed minerals including calcium and fat removal using an acid or alkaline solution. For this stage, acetic acid (groups 1,2,3) and sodium hydroxide are used (groups 9, 10, 
11) where soaking time, neutralization with acid / base, temperature and hydrolysis methods, temperature and drying method were constant.

Gelatins produced from these extraction conditions (Table 3) show that the use of acetic acid produces gelatin with a higher viscosity and meets the requirements of the international standards of viscosity also accordance with the international standards of $\mathrm{pH}$ of gelatin. In the use of sodium hydroxide bases, only $0.1 \mathrm{~N}$ and $1 \mathrm{~N} \mathrm{NaOH}$ concentrations meet the viscosity requirements, but do not meet the acidity requirements, while $0.01 \mathrm{~N} \mathrm{NaOH}$ that used according with requirements.

From this initial procedure, the gelatin produced from milkfish bone that used acetic acid resulted viscosity $(2.7868 \mathrm{cP})$ and acidity (pH 5.3) according to requirements and form powder yellowish color (Table 2). The results obtained were very different from those issued by Zhou \& Regenstain on gelatin extraction of Pollock Alaska fish skin (Zhou \& Regenstein, 2010) related to pretreatment for alkaline. Using pre-treated acid causes degradation of collagen, even using weak acids with low $\mathrm{H}$ concentrations at low temperatures. The presence of proteases that are thought to cause degradation of the extract before using $\mathrm{NaOH}$ or $\mathrm{Ca}(\mathrm{OH})$ 2 at concentrations of $0.1 \mathrm{~mol} / \mathrm{L} \mathrm{OH}$, or acetic acid at a concentration of $0.05 \mathrm{~mol} / \mathrm{L}$ can significantly reduce degradation by proteases. The combination of alkaline pretreatment followed by acid pretreatment not only removes non-collagen proteins, but also provides the right $\mathrm{pH}$ for extraction, and not only removes non-collagen proteins, but also provides the right $\mathrm{pH}$ for extraction, where there are several bonds with less damage to polypeptide chains (Zhou \& Regenstein, 2010). If this applies to the extraction gelatin from milkfish bones and scales, the concentration of acid and base in pretreatment requires a deep study about concentration, temperature and soaking time.

The hydrolysis of ossein (the resulted from process before) was carried out to break the long chain amino acid polymer into a simpler gelatin. This process depen on the temperature and soaking time as well as the kinetic energy given. For this stage, different equipment used are water bath $\left(60^{\circ} \mathrm{C}, 8\right.$ hours $)$, sonicator $\left(50^{\circ} \mathrm{C}, 3\right.$ hours $)$, microwave $\left(100^{\circ} \mathrm{C}, 1\right.$ hour $)$, and autoclave $\left(121^{\circ} \mathrm{C}, 1\right.$ hour) (group $\left.4,5,6,7\right)$ with fixed conditions for the preliminary procedure (1N acetic acid and oven method).

Optimization of the hydrolysis method showed that hydrolysis using a temperature of $60^{\circ} \mathrm{C}$ for 8 hours gave the best viscosity results. While microwave use, sonicator and autoclave produce gelatin with lower viscosity, do not meet requirements for viscosity or acidity (groups 5,6). The low viscosity value was caused longer soaked time that made increase terminating the amino acid chain into a shorter chain. Gelatin from bone had poor viscosity. The structure of gelatin is easily degraded by the heat process becoming shorter chain so the lower the value of the resulting viscosity. The viscosity of gelatin from bone did not meet the requirements of international gelatin standards.

Table 3 Characteristics of Gelatin from Milkfish Bone and Scales

\begin{tabular}{ccccccc}
\hline \multirow{2}{*}{$\begin{array}{c}\text { Grou } \\
\mathbf{p}\end{array}$} & \multicolumn{2}{c}{ viscosity (cP) } & \multicolumn{2}{c}{$\mathbf{p H}$} & \multicolumn{2}{c}{ Yield (\%) } \\
\cline { 2 - 7 } & Bone & Scale & Bone & Scale & Bone & Scale \\
\hline $\mathbf{1}$ & $\mathbf{3 . 8 8 5 4}^{\mathrm{b}}$ & 5.2337 & $\mathbf{5 . 9}^{\mathrm{a}}$ & $\mathbf{6 . 2}^{\mathrm{a}}$ & 0.4 & 2.8 \\
\hline $\mathbf{2}$ & 3.5186 & $\mathbf{5 . 4 2 8 8}^{\mathbf{b}}$ & $\mathbf{5 . 9}^{\mathrm{a}}$ & $\mathbf{5 . 6}^{\mathrm{a}}$ & 1.4 & 1.9 \\
\hline $\mathbf{3}$ & 2.7868 & 5.3256 & 5.3 & $\mathbf{6 . 7}^{\mathrm{a}}$ & 0.2 & 0.2 \\
\hline $\mathbf{4}$ & $\mathbf{2 . 8 1 1 0}^{\mathbf{c}}$ & $\mathbf{3 . 9 4 4 8}^{\mathbf{c}}$ & 5.0 & 5.2 & 2.5 & 3.3 \\
\hline $\mathbf{5}$ & $1.2285^{\mathrm{a}}$ & 1.6923 & 5.5 & $6.0^{\mathrm{a}}$ & 0.6 & 0.3 \\
\hline $\mathbf{6}$ & $1.1176^{\mathrm{a}}$ & 3.1628 & 5.4 & $5.6^{\mathrm{a}}$ & 2.1 & 0.5 \\
\hline $\mathbf{7}$ & 1.8546 & 2.0085 & 5.1 & 5.4 & 9.3 & 5.8 \\
\hline $\mathbf{8}$ & $\mathbf{3 . 3 8 9 0}^{\mathbf{d}}$ & $\mathbf{4 . 6 7 5 9}^{\mathrm{d}}$ & 4.6 & 5.4 & 1.9 & 3.7 \\
\hline $\mathbf{9}$ & $1.5829^{\mathrm{a}}$ & $1.4109^{\mathrm{a}}$ & 7.1 & 6.5 & 0.6 & 2.4 \\
\hline $\mathbf{1 0}$ & $\mathbf{2 . 2 9 0 1}^{\mathrm{e}}$ & $\mathbf{2 . 9 7 3 3}^{\mathrm{e}}$ & $8.8^{\mathrm{a}}$ & $10.0^{\mathrm{a}}$ & 2.3 & 2.8 \\
\hline $\mathbf{1 1}$ & 2.1398 & 2.4199 & $8.3^{\mathrm{a}}$ & $10.7^{\mathrm{a}}$ & 4,6 & 1.4 \\
\hline
\end{tabular}

a: did not meet the standards

b: viscosity differs significantly $\mathrm{p}<0.05$; based on the concentration of Acetic Acid (groups 1-3)

c: viscosity differs significantly $\mathrm{p}<0.05$; based on extraction methods (groups $4-7$ )

$\mathrm{d}$ : viscosity differs significantly $\mathrm{p}<0.05$; based on the drying methods (group 4.8)

e: viscosity differs significantly $\mathrm{p}<0.05$; based on $\mathrm{NaOH}$ concentration (groups 9-11)

The drying method is also very influential on the gelatin produced. The drying method that produces the best gelatin viscosity is shown by the drying method using freeze drier $\left(-4^{\circ} \mathrm{C}, 96 \mathrm{~h}\right)$. Drying with dry heat method still allows the hydrolysis of the gelatin solution during the drying process, with availability of water, the acidity of the media and the appropriate temperature, so that the gelatin produced from that methods has a significantly different viscosity $(\mathrm{p}<0.05)$. At dried with freeze dried methods, the hydrolysis process is difficult to occur. The acidity level of gelatin from both drying methods still meets the requirements. 
Figure 1 shows the gelatin from milkfish scales has a higher viscosity than gelatin produced from bone. Higher collagen content in the scales which causes hydrolysis will still provide higher levels of gelatin for the method used. Gelatin produced from milkfish bone used $1 \mathrm{~N}$ acetic acid soaked 8 hours (pretreatment process), using a temperature of $60^{\circ} \mathrm{C}, 8$ hours and used an oven or freeze dried can be used as ingredient for food, soft capsules and tablets granulate. Gelatin from scales can be used as ingredient for food and hard capsules (table 4).

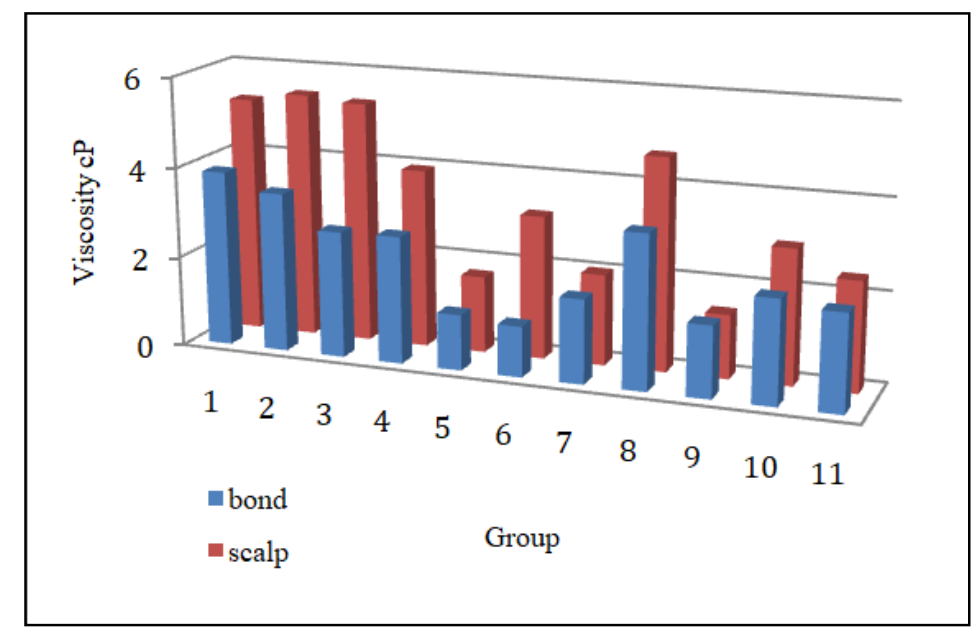

Fig. 1. Gelatin Viscosity of Each Group

Table 4. Comparison of the Viscosity of the Best Gelatin from Milkfish Bones and Scales with International Gelatin GMIA

\begin{tabular}{|c|c|c|}
\hline \multirow{3}{*}{ Group } & & \\
\hline & \multicolumn{2}{|c|}{ viscosity (cP) } \\
\hline & Bone & scale \\
\hline $\begin{array}{l}\text { Group } 4 \\
\text { (1N acetic acid, Water Bath extraction, drying oven) }\end{array}$ & 2.8110 & 3.9448 \\
\hline $\begin{array}{l}\text { Group } 5 \\
\text { (1N acetic acid, Water Bath extraction, freeze dried) }\end{array}$ & 3.3890 & 4.6759 \\
\hline Edible Gelatin GMIA Standard Type A & \multicolumn{2}{|c|}{$1.5-7.5$} \\
\hline Gelatin for hard capsule & \multicolumn{2}{|c|}{ 4.4-5.5 } \\
\hline Gelatin for soft capsule & \multicolumn{2}{|c|}{ 2.5-3.5 } \\
\hline Gelatin for tablet granulates & \multicolumn{2}{|c|}{$1.7-3.5$} \\
\hline Gelatin for photographic & \multicolumn{2}{|c|}{$7.8-9.5$} \\
\hline
\end{tabular}

\section{Conclusion}

From the whole treatment group on the gelatin extraction method, which showed the most optimum method $(\mathrm{p}<0.05)$ for extraction of milkfish bones and scales was used 8-hour soaking with acetic acid (preliminary process), at temperature of $60{ }^{\circ} \mathrm{C}$, $8 \mathrm{~h}$ for the hydrolysis process and used freeze dried method for dried process. The characteristics of gelatin that result shown viscosity and $\mathrm{pH}$ for fish bones, respectively $3.3890 \mathrm{cP}, 4.6$ and $1.9 \%$ while gelatin from scales were $4,6759 \mathrm{cP}, 5.4 \mathrm{and} 3.7 \%$. Gelatin that produce from scale can be used for food and pharmaceutical ingredients (hard capsules); from bone can be used for food and pharmaceutical ingredients (hard, soft capsules and tablets granulations ).

\section{Acknowledgements}

This research was supported by the Ministry of Religion of the Republic of Indonesia through research grants and PT Usaha Centraljaya Sakti, South Sulawesi, Indonesia that gave us raw material milkfish bones and scales. 


\section{References}

[1] Abd Elgadir, M., Mirghani, M. E. S., \& Adam, A. (2013). Fish gelatin and its applications in selected pharmaceutical aspects as alternative source to pork gelatin. Journal of Food, Agriculture and Environment, 11(1), 73-79. https://doi.org/10.1016/j.ijrobp.2009.09.077

[2] Badii, F., \& Howell, N. K. (2006). Fish gelatin: Structure, gelling properties and interaction with egg albumen proteins. Food Hydrocolloids, 20(5), 630-640. https://doi.org/10.1016/j.foodhyd.2005.06.006

[3] Benjakul, S., Kittiphattanabawon, P., \& Regenstein, J. M. (2012). Fish Gelatin. In Food Biochemistry and Food Processing: Second Edition (1st ed., Vol. 60). https://doi.org/10.1002/9781118308035.ch21

[4] Choi, S. S., \& Regenstein, J. M. (2000). Physicochemical and sensory characteristics of fish gelatin. Journal of Food Science, 65(2), 194-199. https://doi.org/10.1111/j.1365-2621.2000.tb15978.x

[5] Dinçer, M. T., Ağçay, Ö. Y., Sargin, H., \& Bayram, H. (2015). Functional properties of gelatin recovered from scales of farmed sea bass (Dicentrarchus labrax). Turkish Journal of Veterinary and Animal Sciences, 39(1), 102-109. https://doi.org/10.3906/vet-1406-68

[6] GMIA. (2012). Gelatin handbook. GIMA, Gelatin Manufacturers Institute of America, 25. Retrieved from http://gelatingmia.com/images/GMIA_Gelatin_Manual_2012.pdf

[7] Koli, J. M., Sagar, B. V, Kamble, R. S., \& Sharangdhar, S. T. (2014). Functional Properties of Gelatin Extracted From Four Different Types of Fishes : a Comparative Study. Indian Journal of Fundamental and Applied Life Sciences, 4(4), 322-327.

[8] Nurul, A.G. \& Sarbon, N. M. (2015). Effects of $p H$ on functional, rheological and structural properties of eel (Monopterus sp.pdf. (January), 572-583.

[9] Rawdkuen, S., Thitipramote, N., \& Benjakul, S. (2013). Preparation and functional characterisation of fish skin gelatin and comparison with commercial gelatin. International Journal of Food Science and Technology, 48(5), $1093-1102$. https://doi.org/10.1111/ijfs.12067

[10] Silva, E. V. C. da, Lourenço, L. de F. H., \& Pena, R. S. (2017). Optimization and characterization of gelatin from kumakuma ( Brachyplatystoma filamentosum ) skin. CyTA - Journal of Food, 15(3), 361-368. https://doi.org/10.1080/19476337.2016.1266391

[11] Silvipriya, K. S., Krishna Kumar, K., Bhat, A. R., Dinesh Kumar, B., John, A., \& Lakshmanan, P. (2015). Collagen: Animal sources and biomedical application. Journal of Applied Pharmaceutical Science, 5(3), $123-127$. https://doi.org/10.7324/JAPS.2015.50322

[12] Sompie, M., Mirah, A. D., \& Karisoh, L. C. H. M. (2015). Pengaruh perbedaan suhu ekstraksi terhadap karakteristik gelatin kulit kaki ayam Effect of extraction temperature difference on characteristics of chicken leg skin gelatin. 1, 792795. https://doi.org/10.13057/psnmbi/m010420

[13] Tavakolipour, H. (2011). Extraction and Evaluation of Gelatin from Silver Carp Waste. World Journal of Fish and Marine Sciences, 3(1), 10-15.

[14] Zakaria, S., Hidayah, N., \& Bakar, A. (2015). Extraction and characterization of gelatin from black tilapia (Oreochromis niloticus) scales. Int'l Conf. on Advances in Science, Engg., Technology \& Natural Resources, 77-80. https://doi.org/10.1063/1.4919191

[15] Zhou, P., \& Regenstein, J. M. (2010). Effects of Alkaline and Acid Pretreatments on Alaska Pollock Skin Gelatin Extraction. Journal of Food Science, 70(6), c392-c396. https://doi.org/10.1111/j.1365-2621.2005.tb11435.x 